\title{
Sorption of lead by chemically modified rice bran
}

\author{
T. Fatima $\cdot$ R. Nadeem $\cdot$ A. Masood $\cdot$ \\ R. Saeed $\cdot$ M. Ashraf
}

Received: 16 August 2011/Revised: 29 April 2012/ Accepted: 5 January 2013/Published online: 17 April 2013

(C) Islamic Azad University (IAU) 2013

\begin{abstract}
In this work, the effectiveness of native and chemically modified rice bran to remove heavy metal $\mathrm{Pb}$ (II) ions from aqueous solution was examined. Chemical modifications with some simple and low-cost chemicals resulted in enhancement of the adsorption capacities and had faster kinetics than native rice bran. Experiments were conducted in shake flasks to monitor the upshot of parameters over a range of $\mathrm{pH}$, initial $\mathrm{Pb}(\mathrm{II})$ concentrations and contact times using a batch model study. The sorption capacities $q\left(\mathrm{mg} \mathrm{g}^{-1}\right)$ increased in the following order: $\mathrm{NaOH}$ (147.78), $\mathrm{Ca}(\mathrm{OH})_{2}$ (139.08), $\mathrm{Al}(\mathrm{OH})_{3}$ (127.24), esterification (124.28), $\mathrm{NaHCO}_{3}$ (118.08), methylation (118.88), $\mathrm{Na}_{2} \mathrm{CO}_{3}$ (117.12) and native (80.24). The utmost uptake capacity $q\left(\mathrm{mg} \mathrm{g}^{-1}\right)$ was shown by $\mathrm{NaOH}$-pretreated rice bran. The results showed that, using $\mathrm{NaOH}$-modified rice bran, the chief removal of $\mathrm{Pb}$ (II) was $74.54 \%$ at $\mathrm{pH}$, primary $\mathrm{Pb}(\mathrm{II})$ concentration $100 \mathrm{mg} \mathrm{L}^{-1}$ and contact time $240 \mathrm{~min}$. Equilibrium isotherms for the $\mathrm{Pb}$ (II) adsorption were analyzed by Langmuir and Freundlich isotherm models. The Langmuir isotherm model, showing $\mathrm{Pb}(\mathrm{II})$ sorption as accessible through the high value of the correlation coefficient $\left(R^{2}=0.993\right)$, showed a $q_{\max }$ value of $416.61 \mathrm{mg} \mathrm{g}^{-1}$. The kinetic model illustrated adsorption
\end{abstract}

T. Fatima $\cdot$ R. Nadeem $(\bowtie) \cdot$ M. Ashraf

Department of Chemistry, University of Agriculture, Faisalabad 38040, Pakistan

e-mail: raziyaanalyst@yahoo.com

A. Masood

Department of Botany, University of Agriculture, Faisalabad 38040, Pakistan

R. Saeed

Department of Management Science, COMSATS Institute of Information Technology, Sahiwal Campus 57000, Pakistan rates well, depicted by a second order, which gives an indication concerning the rate-limiting step. Thermodynamic evaluation of the metal ion $\Delta G^{\mathrm{o}}$ was carried out and led to the observation that the adsorption reaction is spontaneous and endothermic in nature. $\mathrm{NaOH}$ chemically modified rice bran was a superb biosorbent for exclusion of $\mathrm{Pb}(\mathrm{II})$ and proved to be excellent for industrial applications.

Keywords Equilibrium isotherm · Gibbs free energy · Industrial wastewater $\cdot$ Pretreatments

\section{Introduction}

In various industries, increased use of heavy metals leads to their appearance in wastewater (Faisal and Hasnain 2004; Chang et al. 2007). Water becomes polluted because of the input of industrial as well as domestic wastewater, damaging many species (Jude and Augustin 2003; Michael and Ayebaemi 2005). Of the primarily noxious metals originating in the surroundings, $\mathrm{Pb}(\mathrm{II})$ is an important one and causes high toxicity (Pussadee et al. 2008). Its high affinity to protein leads to inhibition of the central transport of oxygen. This kind of toxicification results in necrosis in the kidneys, nervous system breakdown, anemia, convulsions, behavioral disorders and many indications of metabolic insufficiency. The WHO and Pakistan's Ministry of Health reported that the principle values of $\mathrm{Pb}(\mathrm{II})$ are 0.01 and $0.01-0.05 \mathrm{mg} \mathrm{L}^{-1}$ respectively in drinking water (Quality drinking water, Islamabad June 2005), while in industrial wastewater the $\mathrm{Pb}$ (II) level is $0.5 \mathrm{mg} \mathrm{L}^{-1}$, which is dangerous (NEQS Pakistan 1999). Removing metal ions from wastewater has gained a significant place in controlling environmental pollution over the past 2 decades (Naeem et al. 2006; Hanif et al. 2007). For the reduction and 
remediation of heavy metals in wastewater, filtration, dialysis, ion-exchange, chemical precipitation, reverse osmosis, sedimentation, solvent extraction and adsorption processes have been used (Holan and Volesky 1994; Lee and Volesky 1997). In the biosorption process, biological materials are used to remove metal ions or metalloid species and compounds from solution (Diniz and Volesky 2005). However, currently alternative adsorbents that are inexpensive, have good adsorption properties and improved accessibility are being used in biosorption. Some earlier studies reported that inexpensive residues have the capability to adsorb heavy metals from polluted water and metal solutions, e.g., sunflower stalks (Sun and Shi 1998), waste tea (Mahvi et al. 2005), wheat bran (Bulut and Baysal 2006), almond shells (Dakiky et al. 2002) and distillery sludge from the sugar cane industry (Nadeem et al. 2008). Mosa et al. (2011) suggested that pretreated agricultural biosorbents enhanced the sorption capacity. The main residues of agricultural products are lignin and cellulose, but various supplementary compounds are also found (Sud et al. 2008). Concerning cereal crops, the annual rice production in Pakistan is millions of tons. Rice bran is obtained as a secondary product of milling in the production of refined grains. Using rice bran is an effective and economical implementation of waste material (Zafar et al. 2007). Zafar et al. (2009) reported the FTIR spectra of rice bran, showing the existence of carboxyl groups, surface hydroxyl groups and physically adsorbed water. Spectral exploration early and at the end of metal binding allowed the affirmation of $-\mathrm{NH}$ in metal sorption. These compounds participate in a key function to alleviate the effects of pollution and show nutritive effects on plants. Therefore, the use of bran or natural products significantly eliminates pollution from water. However, using raw crop residues as biosorbents can also create numerous problems because of their small adsorption capacity, elevated COD, BOD and restricted discharge of soluble organic compounds (Nakajima and Sakaguchi 1990). Consequently, chemical alteration of crop residues could remove soluble organic compounds and improve the effectiveness of biosorbent resources. Chemical treatment of biosorbents for extracting soluble organic compounds improves the efficiency of metal adsorption (Wan Ngah and Hanafiah 2008). The chemical treatment of lignocellulose causes bumps, leading to an enlarged interior surface area, reduced polymerization, reduced crystallinity and increased porosity as well as hemicellulose degradation and lignin transformation, thus increasing the potential of cellulose hydrolysis (Kleinert 1966). Modified rice bran has often been used to remove Cd (II) from water (Ye et al. 2010). In our previous studies (Zafar et al. 2007, 2009), rice bran was chemically modified with mineral acids and bases for nickel removal, and the sorption capacity of the biomass was found to increase promisingly. Thus, in the present study, rice bran was chemically modified by alkalis, detergents and complexes to study the effect of pretreatment for $\mathrm{Pb}(\mathrm{II})$ sorption.

This research was carried out from September 2006 to November 2007 at the Research Laboratories, Department of Chemistry, University of Agriculture, Faisalabad, Pakistan.

\section{Materials and methods}

\section{Chemicals and instruments}

All chemicals were pro-analytical grade and were purchased from E. Merck Co. (Darmstadt, Germany). A PerkinElmer (Analyst 300) Atomic Absorption Spectrophotometer was used to measure metal concentrations. A TOA.V. pH meter (HM 30P) was used to check the $\mathrm{pH}$ of metal solutions. Other instruments used were the orbital shaker (PA 250/25. H), Octagon siever (OCT-DIGITAL 4527-01), Shimadzu (AW 220) electric balance and Eyela vacuum oven (VOC-300 SD).

Preliminary preparation of the biomass

Waste rice bran was collected from different shellers in Sialkot and Hafizabad, Pakistan. The samples were then dried at $70{ }^{\circ} \mathrm{C}$ for 1 week. They were washed with water to remove dust particles and desiccated in an Eyela vacuum oven (VOC-300 SD) at $70 \pm 1{ }^{\circ} \mathrm{C}$ for $24 \mathrm{~h}$ until a constant weight was obtained. The dried biosorbent was ground and sieved through an Octagon siever (OCT-DIGITAL 4527-01) to attain homogeneous particle size (0.250-1.0 $\mathrm{mm})$. All samples were stored in airtight plastic jars at room temperature $\left(35 \pm 1{ }^{\circ} \mathrm{C}\right)$.

\section{Chemical modifications of rice bran}

The chemicals used for pretreatment were $\mathrm{NaOH}$, $\mathrm{Ca}(\mathrm{OH})_{2}, \mathrm{Al}(\mathrm{OH})_{3}, \mathrm{Na}_{2} \mathrm{CO}_{3}$ and $\mathrm{NaHCO}_{3}$ for esterification and methylation. In order to determine the upshot of the chemical modification on the adsorption capacity of the biosorbent, $20 \mathrm{~g}$ of rice bran was taken and treated with I M $(200 \mathrm{~mL})$ of each chemical separately for $24 \mathrm{~h}$.

For esterification, $5 \mathrm{~g}$ of rice bran was used with $500 \mathrm{~mL}$ of anhydrous methanol and $5 \mathrm{~mL}$ of concentrated $\mathrm{HCl}$ and shaken in an Orbital shaker (PA 250/25. H) for $8 \mathrm{~h}$ at $130 \mathrm{rpm}$. The general esterification reaction followed Kapoor and Viraghran (1997).

$\mathrm{RCOOH}+\mathrm{CH}_{3} \mathrm{OH} \stackrel{\mathrm{H}^{+}}{\rightarrow} \mathrm{RCOOCH}_{3}+\mathrm{H}_{2} \mathrm{O}$

For methylation $5 \mathrm{~g}$ of rice bran was subjected to treatment with $100 \mathrm{~mL}$ of $\mathrm{HCHO}$ and $200 \mathrm{~mL}$ of $\mathrm{HCOOH}$, 
and the mixture was shaken for $8 \mathrm{~h}$ at $130 \mathrm{rpm}$. The reaction occurred as follows (Park et al. 2005).

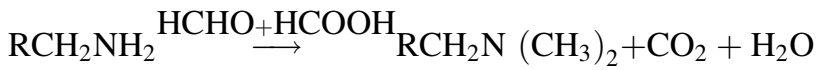

After shaking, all samples were filtered through $0.45-\mu \mathrm{m}$ Millipore filter paper and cleaned several times with distilled water until reaching neutral $\mathrm{pH}$. The chemically modified rice bran was dried in an oven at $70{ }^{\circ} \mathrm{C}$. After grinding, the biosorbent was sieved to obtain $0.250-\mathrm{mm}$ particle size. The native biomass was also sieved.

\section{Batch sorption studies}

All experiments were performed with chemically modified and native biomass to test the metal-binding capacity. Stock $\mathrm{Pb}(\mathrm{II})$ solution $\left(1,000 \mathrm{mg} \mathrm{L}^{-1}\right)$ was prepared by dissolving $1.598 \mathrm{~g}$ of $\mathrm{Pb}\left(\mathrm{NO}_{3}\right)_{2}$ in distilled water. To adjust the $\mathrm{pH}$ of the solution, $0.1 \mathrm{~N} \mathrm{HCl}$ and $\mathrm{NaOH}$ were used. Different operational parameters such as the $\mathrm{pH}(3-6)$ and initial metal $\mathrm{Pb}(\mathrm{II})$ concentration $(50,100,150,200,400$ and $\left.600 \mathrm{mg} \mathrm{L}^{-1}\right)$ were studied at biosorbent dose $(0.05 \mathrm{~g})$ and biosorbent particle size $(0.250 \mathrm{~mm})$ in an Orbital shaker at $130 \mathrm{rpm}$ for $24 \mathrm{~h}$. After removal of the flasks from the shaker, the solutions were filtered, and filtrates were stored in precleaned and acid $\left(\mathrm{HNO}_{3}\right)$-washed airtight plastic bottles. Metal concentrations were analyzed by an operational PerkinElmer (A Analyst) Atomic Absorption Spectrophotometer with a $\mathrm{Pb}$ (II) hollow cathode lamp in service at a wavelength of $232 \mathrm{~nm}$ and slit as $0.2 \mathrm{~nm}$. The metal uptake capacity ' $q$ ' $\left(\mathrm{mg} \mathrm{g}^{-1}\right)$ was calculated as given.

$q=V\left(C_{\mathrm{i}}-C_{\mathrm{e}}\right) / M$

In this equation, $V$ is the volume of the solution $(\mathrm{L}), C_{\mathrm{i}}$ is the initial $\mathrm{Pb}$ (II) concentration $\left(\mathrm{mg} \mathrm{L}^{-1}\right), C_{\mathrm{e}}$ is the $\mathrm{Pb}(\mathrm{II})$ concentration at equilibrium $\left(\mathrm{mg} \mathrm{L}^{-1}\right)$, and $M$ is the mass of the biosorbent $(\mathrm{g})$.

\section{Result and discussion}

\section{Effect of chemical modifications}

To evaluate the effect of chemical modification of biomass, $100 \mathrm{mg} \mathrm{L}^{-1}$ lead (II) solution was shaken at $130 \mathrm{rpm}$ with $0.05 \mathrm{~g}$ of biosorbent having a size of $0.255 \mathrm{~mm}$ at $\mathrm{pH} 5$ for $24 \mathrm{~h}$. Enhancement or reduction of the sorption capacity of the biomass by chemical modifications of the biosorbent with alkalis, detergent and complexes was studied and is shown in Fig. 1. As a result of chemical modifications of rice bran, the metal uptake capacity $q\left(\mathrm{mg} \mathrm{g}^{-1}\right)$ was

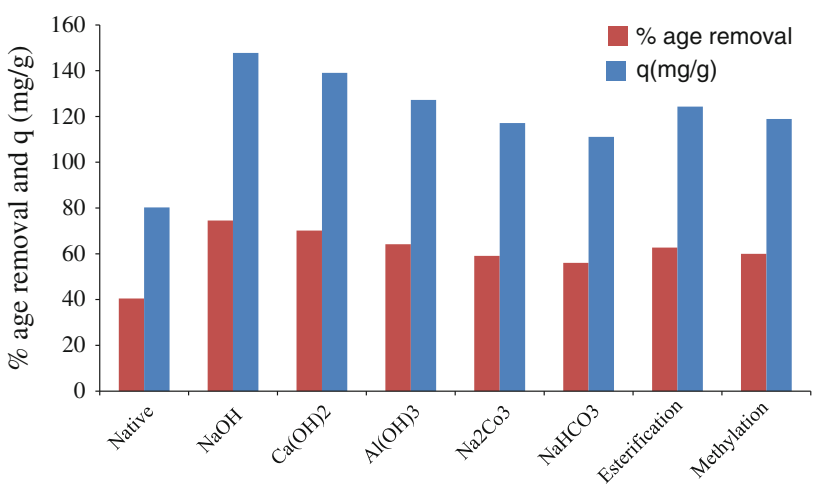

Chemical modifications

Fig. 1 Effect of chemical modification on sorption of $\mathrm{Pb}(\mathrm{II})$ by rice bran

enhanced in this order: $\mathrm{NaOH}(147.78), \mathrm{Ca}(\mathrm{OH})_{2}(139.08)$, $\mathrm{Al}(\mathrm{OH})_{3}$ (127.24), esterification (124.28), methylation (118.88), $\mathrm{Na}_{2} \mathrm{CO}_{3}$ (117.12), $\mathrm{NaHCO}_{3}$ (111.08), and native (80.24).

Among alkaline modifications of biomass, $\mathrm{NaOH}$ showed a paramount metal uptake capacity because it provides more carboxylate ligands for metal-binding sites. Alkaline pretreatment of the biomass augmented sorption because of removal of surface impurities, cracking of the cell membrane and exposure of the available binding sites for metal (Nasir et al. 2007). The main components of agricultural crop residues are cellulose, hemicellulose and lignin, which include methyl esters that are not combined with metal ions, mostly in an unmodified state. Methyl esters were distorted to carboxylate ligands when treated with a base, which increased the metal-attachment ability of the biosorbent (Rehman et al. 2006).

$$
\begin{aligned}
\mathrm{R}-\mathrm{COOCH}_{3}+\mathrm{NaOH} \rightarrow & \mathrm{R}-\mathrm{COO}^{-}+\mathrm{CH}_{3} \mathrm{OH} \\
& +\mathrm{Na}^{+}
\end{aligned}
$$

The chemical modification of the biomass with detergents such as $\mathrm{Na}_{2} \mathrm{CO}_{3}$ and $\mathrm{NaHCO}_{3}$ enhanced the sorption capacity. This is because detergent pretreatment causes severe degradation of the biosorbent cell wall, and minerals end up exposing more binding sites and porosity for metal uptake. Among the detergent pretreatments, $\mathrm{Na}_{2} \mathrm{CO}_{3}$ causes extra degradation resulting in elevated sorption as compared to $\mathrm{NaHCO}_{3}$.

Studies show that pretreatment of the biomass with methanol and hydrochloric acid causes esterification of the carboxyl group present on the biomass. Treatment with formaldehyde and formic acid was predicted to cause methylation of the amino group (Kapoor and Viraraghavan 1995).

Modification of the biomass also increases the percentage of biomass removal by up to 48 and $55 \%$ after 
methylation and esterification, respectively. Esterification modification caused enhancement by deposition of more carboxyl groups on the surface of the biomass. In methylation, amino groups reside more over the surface of the biomass, causing sorbtion of more metal ions (Feng et al. 2010). Enhancement or reduction in the sorption capacity of the biomass occurs by eradicating, covering or exposing the available binding sites.

\section{Effect of the initial $\mathrm{pH}$ of the solution on $\mathrm{Pb}(\mathrm{II})$ sorption}

The $\mathrm{pH}$ is a dynamic and imperative environmental factor controlling heavy metals' site dissociation, speciation, adsorption, accessibility and solution chemistry ( $\mathrm{Li}$ et al. 2007; Costodes et al. 2003). To investigate the effect of this parameter on metal sorption by native and chemically modified rice bran, experiments were conducted at an initial metal concentration of $100 \mathrm{mg} \mathrm{L}^{-1}, 0.25 \mathrm{~mm}$ size and $0.05 \mathrm{~g}$ of biosorbent, and the initial $\mathrm{pH}$ of the solution varied in the range of 3-6. At lower $\mathrm{pH}$, the biosorbent sites are concentrated by hydronium ions that constrain the approach of metal ions to cells (Mehrasbi et al. 2009), and on rising $\mathrm{pH}$ the hydroxyl groups reside on the binding site and exert a pull on positive metal ions. At higher $\mathrm{pH}$, metal hydroxide precipitation takes place, but sorption studies are unfeasible (Sekhar et al. 2004). Thus, at lower and higher $\mathrm{pH}$, the sorption capacity is less, which is analogous to the results of earlier studies (Singh et al. 2005). As pH increases from $3-5$, the percentage reduction of the $\mathrm{Pb}(\mathrm{II})$ concentration increases because of the available binding sites, and at $\mathrm{pH} 6$ the percentage removal decreases because of hydroxide precipitation. The maximum percentage removal of $\mathrm{Pb}$ (II) was $74.5 \%$ at $\mathrm{pH} 5$ using $\mathrm{NaOH}$-pretreated rice bran. The maximum metal uptake capacity was observed for chemically modified $\mathrm{NaOH}$ $\left(147.78 \mathrm{mg} \mathrm{g}^{-1}\right)>\mathrm{Ca}(\mathrm{OH})_{2}\left(139.08 \mathrm{mg} \mathrm{g}^{-1}\right)>\mathrm{Al}(\mathrm{OH})_{3}$ $\left(127.24 \mathrm{mg} \mathrm{g}^{-1}\right)>\mathrm{Na}_{2} \mathrm{CO}_{3}\left(117.12 \mathrm{mg} \mathrm{g}^{-1}\right)>\mathrm{NaHCO}_{3}$ $\left(111.08 \mathrm{mg} \mathrm{g}^{-1}\right)>$ Native $\left(80.24 \mathrm{mg} \mathrm{g}^{-1}\right)$ at $\mathrm{pH} 5$ (Fig. 2). Thus, the pH 5 range was chosen to avoid the approach of hydronium ions and metal solid hydroxide precipitation.

\section{Effect of initial metal concentration}

The sorption rate is the task of the initial metal concentration and is an essential aspect for successful adsorption. The effect of the initial metal concentration on $\mathrm{Pb}$ (II) biosorption through native and chemically modified rice bran (biosorbent) was studied at $0.25-\mathrm{mm}$ biosorbent size and $0.05-\mathrm{g}$ biosorbent dose with the solution at $\mathrm{pH} 5$. The initial metal concentration was in the range of 50, 100, 150, 200, 400 and $600 \mathrm{mg} \mathrm{L}^{-1}$. Thus, the metal uptake capacity of native and chemically modified biosorbent increases

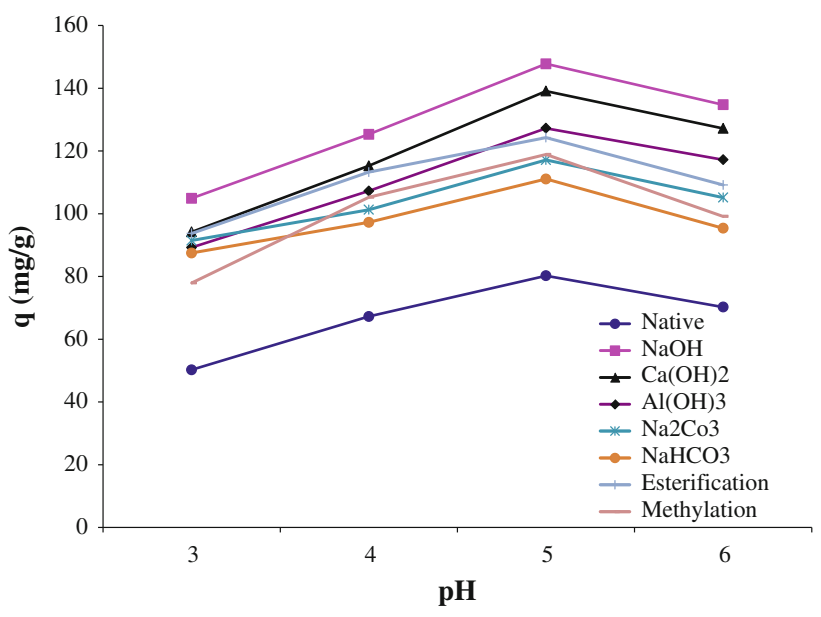

Fig. 2 Effect of $\mathrm{pH}$ on the sorption of $\mathrm{Pb}$ (II) by chemically modified rice bran

with an increase in the metal ion concentration, while the percentage removal was greatest at $100 \mathrm{mg} \mathrm{L}^{-1}$ and then decreased with increases in the metal concentration. The sorption characteristics allow surface saturation to occur because of the increase in metal concentration. The initial $\mathrm{Pb}(\mathrm{II})$ concentration causes an increase in the adsorption capacity $(q)$ from 50 to $600 \mathrm{mg} \mathrm{L}^{-1}$. At low concentration, all binding sites were accessible for adsorption. At higher concentration, the number of available adsorption sites was limited, and take up of the biosorbent particles became sluggish. Intraparticle diffusion on the biosorbent surface resulted in the parting of more metal ions in solution. (Amuda et al. 2007; Conference on Urban Drain, 2005). The results showed that the sorption capacity of the biomass increased with an increase in metal ion concentration. The maximum $q$ value for the metal uptake capacity was observed as $\mathrm{NaOH} \quad\left(348.42 \mathrm{mg} \mathrm{g}^{-1}\right)>\mathrm{Ca}(\mathrm{OH})_{2}$ $\left(288.42 \mathrm{mg} \mathrm{g}^{-1}\right)>\mathrm{Na}_{2} \mathrm{CO}_{3}\left(268.42 \mathrm{mg} \mathrm{g}^{-1}\right)=$ esterification $\left(268.42 \mathrm{mg} \mathrm{g}^{-1}\right)>\mathrm{NaHCO}_{3} \quad\left(248.42 \mathrm{mg} \mathrm{g}^{-1}\right)>$ $\mathrm{Al}(\mathrm{OH})_{3}\left(228.42 \mathrm{mg} \mathrm{g}^{-1}\right)>$ methylation $\left(228.42 \mathrm{mg} \mathrm{g}^{-1}\right)$ $>$ native $\left(188.42 \mathrm{mg} \mathrm{g}^{-1}\right)$ at $\mathrm{pH} 5$ and $600 \mathrm{mg} \mathrm{L}^{-1}$ metal concentration (Fig. 3). This sorption characteristic indicates that surface saturation depends on the metal concentration.

\section{Equilibrium modeling}

The isotherm association signifies the description of the sorption mechanism, surface behavior of the biosorbent and the solute quantity in the solution at equilibrium (Seader and Henley 2006). In this study, Langmuir and Freundlich isotherm models were used. Diffusion of metal ions onto binding sites because of the wealth of elevated concentrations is attuned by the linearized form of the Langmuir isotherm (Schiewer and Patil 2008). 


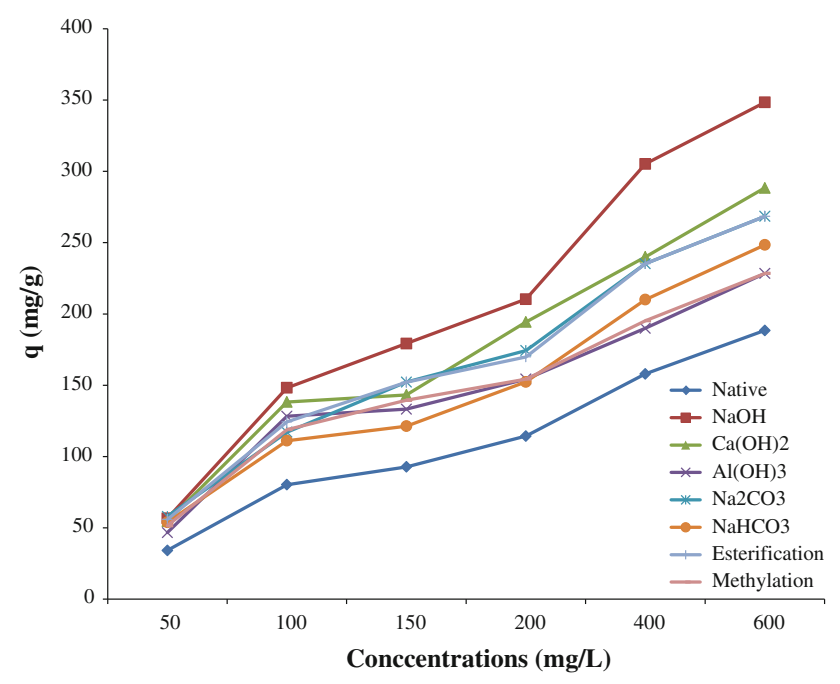

Fig. 3 Effect of initial metal ion concentration on sorption of $\mathrm{Pb}$ (II) by chemically modified rice bran

$C_{\mathrm{e}} / q_{\mathrm{e}}=1 / X_{\mathrm{m}} K_{\mathrm{L}}+C_{\mathrm{e}} / X_{\mathrm{m}}$

In this equation, $X_{\mathrm{m}}$ is the theoretical sorption capacity of the biomass $\left(\mathrm{mg} \mathrm{g}^{-1}\right)$ and $K_{\mathrm{L}}$ is the apparent energy of sorption $\left(\mathrm{dm}^{3} \mathrm{~g}^{-1}\right)$. A review of $R^{2}$ values greater than 0.95 for all pretreated biomasses suggested this model to be most favorable to explain sorption. The constant $K_{\mathrm{L}}$ represented the affinity between sorbate and the sorbent, so its high value indicated high affinity of sorbents for the sorbate (Table 1).

The Freundlich isotherm is basically attributed to interpretations of adsorption on heterogeneous surfaces. It is suggested that stronger binding sites are engaged foremost, and the binding power is decreased due to the sites unavailability (Chang et al. 2003). The linearized form of the Freundlich isotherm model is represented as follows.

$\log q_{\mathrm{e}}=(1 / n) \log C_{\mathrm{e}}+\log K$

In this equation, $K$ is the Freundlich constants, and the value of ' $n$ ' in the range of 1-10 shows good sorption. Although the value of ' $n$ ' was greater than unity, which indicates favorable sorption (Table 1), the value of $k$ in this model opposed the experimental trend of sorbents to remove metal ions. Also, the values of $R^{2}$ were low, opposing the fitness of this model to the experimental data. The constants were determined from the plot between log $q_{\mathrm{e}}$ beside $\log C_{\mathrm{e}}$ (Singh et al. 2005). The Langmuir and Freundlich isotherm parameters with the correlation coefficients are given in Table 1. The Langmuir model (Fig. 4) is a well built-in sorption process, in contrast to the Freundlich model (Fig. 5), owing to the large value of the correlation coefficient (Table 1). Thus, it is concluded that the heterogeneous biomass surface was roofed by a monolayer of sorbate. The Langmuir theory explains the sorption phenomenon of this biomass more favorably.

\section{Separation factor}

The essential characteristics of the Langmuir isotherm were shown in expressions of the dimensionless constant separation factor $E_{\mathrm{p}}$, which is defined by the following relationship (Hanif et al. 2007).

$E_{\mathrm{p}}=1 /\left(1+K_{\mathrm{L}} C_{\mathrm{i}}\right)$

In this equation, $K_{\mathrm{L}}$ is the Langmuir constant, and $C_{\mathrm{i}}$ is the initial metal concentration $\left(\mathrm{mg} \mathrm{L}^{-1}\right)$. The values of $E_{\mathrm{p}}$ for $\mathrm{Pb}$ (II) were calculated and plotted against the initial metal ion concentration. $E_{\mathrm{p}}$ values greater than 0 and less than 1 represent a favorable isotherm. Sorption of $\mathrm{Pb}(\mathrm{II})$ by chemically modified rice bran increases with the initial metal ion concentration from 50 to $600 \mathrm{mg} \mathrm{L}^{-1}$, showing that sorption is positive and intended for higher initial metal ion concentrations (Fig. 6).

\section{Surface coverage}

To report in favor of sorption in concert with $\mathrm{Pb}(\mathrm{II})$ on chemically modified rice bran, a Langmuir type equation interrelated to surface coverage was expressed as

$K C_{\mathrm{i}}=\theta / 1-\theta$

Table 1 Equilibrium isotherm model parameters for the sorption of $\mathrm{Pb}$ (II) by chemically modified rice bran

\begin{tabular}{|c|c|c|c|c|c|c|c|c|}
\hline \multirow[t]{2}{*}{ Chemical modifications of rice bran } & \multicolumn{3}{|c|}{ Langmuir isotherm parameters } & \multirow{2}{*}{$\begin{array}{l}\text { Experi. value } \\
q_{\max }\left(\mathrm{mg} \mathrm{g}^{-1}\right)\end{array}$} & \multicolumn{4}{|c|}{ Freundlich isotherm parameters } \\
\hline & $X_{\mathrm{m}}\left(\mathrm{mg} \mathrm{g}^{-1}\right)$ & $K_{\mathrm{L}}$ & $R^{2}$ & & $q_{\mathrm{e}}\left(\mathrm{mg} \mathrm{g}^{-1}\right)$ & $K_{\mathrm{F}}$ & $1 / n$ & $R^{2}$ \\
\hline Native & 250.0 & $2.6 \times 10^{-3}$ & 0.682 & 188.4 & 207.0 & 6.470 & 0.56 & 0.912 \\
\hline $\mathrm{NaOH}$ & 416.6 & $4.9 \times 10^{-4}$ & 0.973 & 348.4 & 372.7 & 22.13 & 0.47 & 0.803 \\
\hline $\mathrm{Ca}(\mathrm{OH})_{2}$ & 333.0 & $7.4 \times 10^{-4}$ & 0.975 & 288.4 & 308.3 & 21.03 & 0.44 & 0.814 \\
\hline $\mathrm{Al}(\mathrm{OH})_{3}$ & 263.1 & $1.3 \times 10^{-3}$ & 0.964 & 228.4 & 237.0 & 18.90 & 0.41 & 0.725 \\
\hline $\mathrm{Na}_{2} \mathrm{CO}_{3}$ & 312.5 & $8.0 \times 10^{-4}$ & 0.993 & 268.4 & 282.0 & 19.40 & 0.44 & 0.927 \\
\hline $\mathrm{NaHCO}_{3}$ & 294.1 & $1.1 \times 10^{-3}$ & 0.987 & 248.4 & 282.8 & 16.06 & 0.45 & 0.940 \\
\hline Esterification & 303.0 & $8.4 \times 10^{-3}$ & 0.990 & 268.4 & 288.6 & 19.83 & 0.44 & 0.881 \\
\hline Methylation & 256.4 & $1.0 \times 10^{-3}$ & 0.982 & 228.4 & 235.5 & 20.15 & 0.40 & 0.822 \\
\hline
\end{tabular}




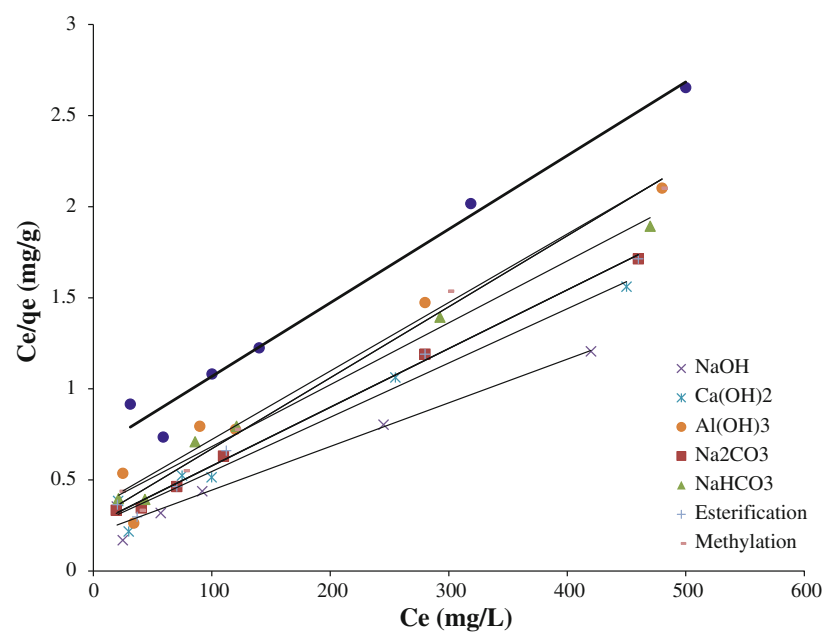

Fig. 4 Langmuir isotherm plot for sorption of $\mathrm{Pb}(\mathrm{II})$ by chemically modified rice bran

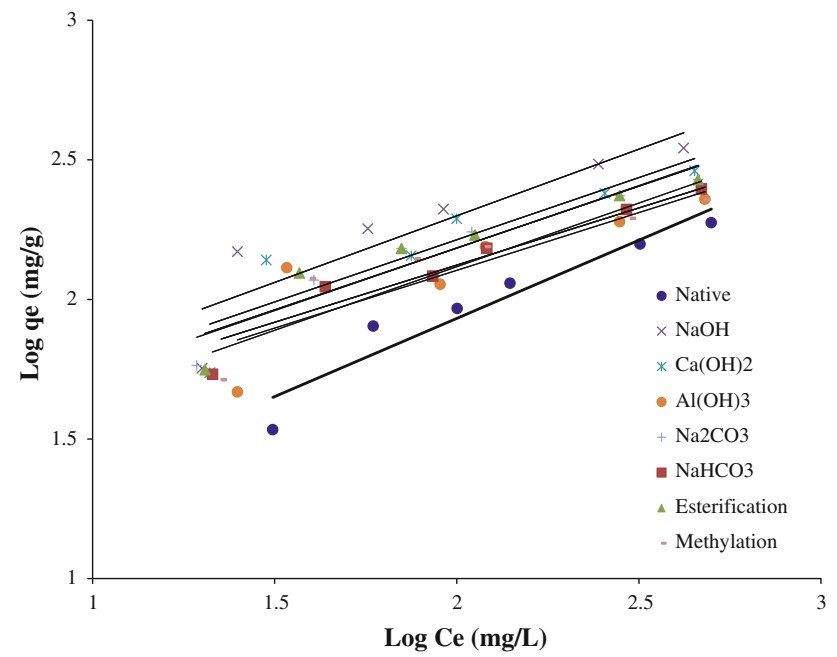

Fig. 5 Frenduilch isotherm plot for sorption of $\mathrm{Pb}(\mathrm{II})$ by chemically modified rice bran

where $\theta$ is the surface coverage, $C_{\mathrm{i}}$ the initial concentration and $K$ an adsorption coefficient (Zeng et al. 2004). Figure 7 shows the surface coverage data. Surface coverage of the biosorbent enhances with an increase in the concentration of the initial metal to the surface build up by means of a monomolecular layer. It can also be seen that surface coverage tends to be nearly constant with small differences in the surface coverage parameter at high metal ion concentrations. The reaction rate becomes independent of the metal ion concentration. The overall adsorption process indicates that the reaction is first order at lower metal ion concentrations and zero order at higher concentrations, indicating that the biomass will be highly effective in removing trace amounts of $\mathrm{Pb}$ (II) ion in aqueous effluent.

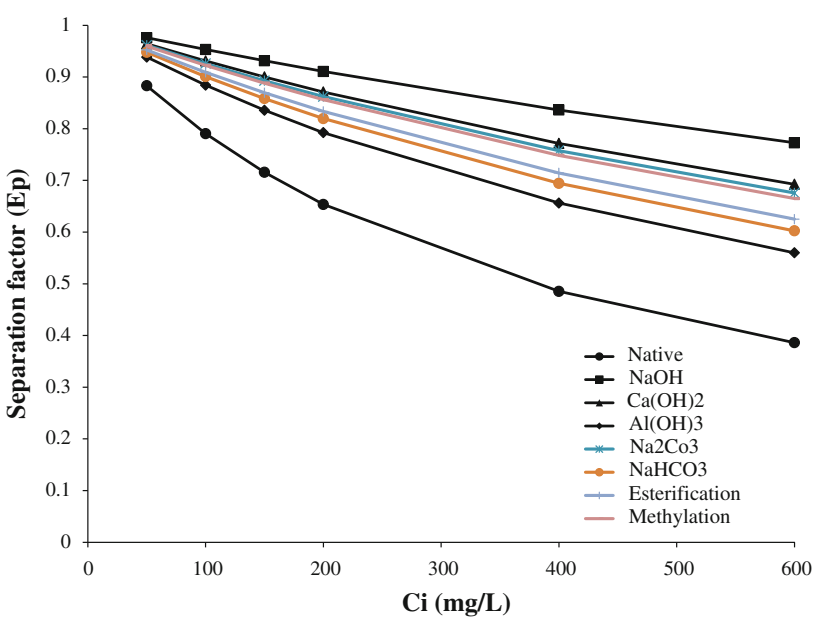

Fig. 6 Separation factor profile for sorption of $\mathrm{Pb}(\mathrm{II})$ by chemically modified rice bran

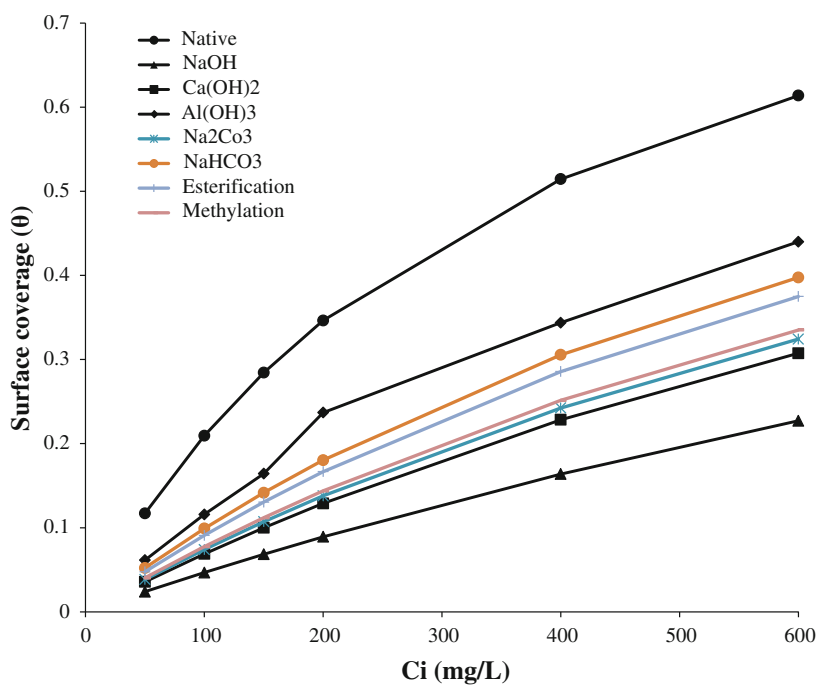

Fig. 7 Surface coverage profile for sorption of $\mathrm{Pb}(\mathrm{II})$ by chemically modified rice bran

Distribution coefficient

The distribution coefficient $(D)$ can be defined as "the ratio of metal concentration in the adsorbent phase to the concentration in the aqueous phase" (Jnr and Spiff 2005). The biosorbent comparativeness in removing $\mathrm{Pb}$ (II) ions from aqueous solution can be estimated according to stipulations of the distribution coefficient. The distribution coefficient (D) values computed for a range of $\mathrm{Pb}(\mathrm{II})$ concentrations were recorded. It is fairly apparent from the results that the concentration of metal ions at the sorbent-water interface is higher than the concentration in the continuous aqueous phase. This suggests that the biomass is efficient in the removal of $\mathrm{Pb}$ (II) from aqueous solutions. The nature of the sorbed species may be concluded from the actuality that the 
Table 2 Distribution ratio, $D$ of $\mathrm{Pb}$ (II) between chemically modified rice bran and aqueous phase

\begin{tabular}{lllllll}
\hline $\begin{array}{l}\text { Concentration }\left(\mathrm{mg} \mathrm{L}^{-1}\right) \\
\begin{array}{l}\text { Chemical modifications } \\
\text { of rice bran }\end{array}\end{array}$ & $\begin{array}{l}50 \\
\text { Distribution ratio }(D)\end{array}$ & & 150 & 200 & 400 & 600 \\
\hline $\mathrm{Native}$ & 0.3532 & 0.4047 & 0.3162 & 0.2866 & 0.1986 & 0.1585 \\
$\mathrm{NaOH}$ & 0.5860 & 0.7477 & 0.6112 & 0.5334 & 0.3838 & 0.2931 \\
$\mathrm{Ca}(\mathrm{OH})_{2}$ & 0.5653 & 0.6973 & 0.4884 & 0.4928 & 0.3200 & 0.2426 \\
$\mathrm{Al}(\mathrm{OH})_{3}$ & 0.4826 & 0.6468 & 0.4543 & 0.3914 & 0.2533 & 0.1922 \\
$\mathrm{Na}_{2} \mathrm{CO}_{3}$ & 0.5999 & 0.5907 & 0.5190 & 0.4421 & 0.2958 & 0.2258 \\
$\mathrm{NaHCO}_{3}$ & 0.5579 & 0.5603 & 0.4135 & 0.3863 & 0.2640 & 0.2090 \\
Esterification & 0.5784 & 0.6269 & 0.5187 & 0.4307 & 0.2958 & 0.2258 \\
Methylation & 0.5331 & 0.5996 & 0.4758 & 0.3914 & 0.2455 & 0.1922 \\
\hline
\end{tabular}

metal ions are divalent (Table 2). This indicates that two molecules of biomass were associated with metals. Therefore, the composition of the sorbed complex and the possible mechanism can be given as follows (Kratochvil and Volesky 1998).

$\mathrm{M}^{2+}+2 \mathrm{~B}-\mathrm{OH}=\mathrm{M}\left(\mathrm{BO}^{-}\right)_{2}+2 \mathrm{H}^{+}$

where $\mathrm{M}^{2+}$ is the divalent metal ion, $\mathrm{B}$ is the biomass, $\mathrm{OH}^{1-}$ is the hydroxyl group, and $\mathrm{H}^{+}$is the proton. The sorption occurs by an ion-exchange mechanism.

\section{Thermodynamic parameters}

\section{Gibbs free energy}

Gibbs free energy $\left(\Delta G_{\mathrm{ads}}^{0}\right)$ reveals the spontaneous and non-spontaneous nature of sorption methods shown by the following equation (Rudresh and Mayanna 1977).

$$
\begin{aligned}
& \Delta \mathrm{G}_{\mathrm{ads}}^{0}=- 2.303 \mathrm{R} T \log \left[\left\{554 \theta / C_{\mathrm{i}}(1-\theta)\right\}\right. \\
&\left.\times\left\{\theta+n(1-\theta)^{n-1} / n^{n}\right\}\right]
\end{aligned}
$$

The thermodynamics of the exchange process depend on the number of water molecules $(n)$ replaced by the metal ions. Since the most probable value is 2, the apparent Gibbs free energy of the adsorption processes corresponding to $\mathrm{Pb}$ (II) is evaluated. The literature cited reveals that the value of $\left(\Delta G_{\text {ads }}^{0}\right)$ up to $-20 \mathrm{~kJ} \mathrm{~mol}^{-1}$ illustrates electrostatic interactions among metal ions and the biosorbent surface, indicating physisorption, while being more negative than $-40 \mathrm{~kJ} \mathrm{~mol}^{-1}$ signifies chemisorptions, whereas values between -20 to $-40 \mathrm{~kJ} \mathrm{~mol}^{-1}$ show both physisorption and chemisorption mechanisms. The negative value of $\Delta G^{0}$ designates the spontaneous adsorption nature of $\mathrm{Pb}$ (II) by the chemically modified biosorbent (Sekhar et al. 2003). In the present study, the magnitude of the $\Delta G_{\text {ads }}^{0}$ was negative at all concentrations, indicating that sorption of the metal ion by rice bran was spontaneous in nature (Table 3). The range of $\Delta G_{\text {ads }}^{0}$ explained a chemical and physical mechanism for the sorption of $\mathrm{Pb}(\mathrm{II})$ onto the chemically modified rice bran.

\section{Effect of kinetics studies}

The kinetic profile of $\mathrm{Pb}$ (II) sorption by chemically modified rice bran is shown in Fig. 8. The effect of kinetics on the adsorption capacity $(q)$ at a distinct time series from 0 to $24 \mathrm{~h}$ was studied, and the greatest $\mathrm{Pb}$ (II) sorption by chemically modified rice bran occurred within $15 \mathrm{~min}$.

The maximum biosorption was within $15 \mathrm{~min}$. At the beginning, the binding sites of biosorbent were free and easily available and maximum biosorption took place, but as time passed, the biosorption rate became low. It is a well known fact that rapid initial sorption within the first $15 \mathrm{~min}$ is due to extracellular sorption binding and slow sorption results from intracellular binding. After $240 \mathrm{~min}$, the equilibrium was established under the tested conditions, and the biosorption rate became constant (Fig. 8). The maximum percentage removal within the first 15 min by $\mathrm{NaOH}$ modified rice bran was $23.69 \%$, and after $240 \mathrm{~min}$ it was $74.54 \%$. In this study, pretreatment of the biomass by $\mathrm{NaHCO}_{3}$ led to the least percentage removal $(56.03 \%)$. However, pretreatment caused changes in the active sites of the biomass that led to enhanced sorption capacity of the biomass. When the concentration is low, adsorption sites capture accessible metal ions more rapidly (Gadd 1988; Weber 1985).

\section{Kinetic modeling}

Sorption procedures occur through different steps of mechanisms including intraparticle diffusion, physiochemical sorption and extraparticle diffusion at the sorbent site (Ho and Mckay 1999). The transitory behavior of the adsorption procedure was evaluated at different temperatures and metal ions considered by a Lagergren pseudo first-order kinetic model and pseudo second-order model.

The integral form of the pseudo first-order model is generally expressed as (Preetha and Viruthagiri 2005).

$\log \left(q_{\mathrm{e}}-q\right)=\log q_{\mathrm{e}}-k_{1} t / 2.303$

where $q_{\mathrm{e}}$ and $q\left(\mathrm{mg} \mathrm{g}^{-1}\right)$ are adsorption capacities at equilibrium and at time $t$, respectively, and $k_{1}\left(\mathrm{~min}^{-1}\right)$ is the 
Table 3 Thermodynamic parameters of the sorption of $\mathrm{Pb}$ (II) by chemically modified rice bran

\begin{tabular}{|c|c|c|c|c|c|c|}
\hline $\begin{array}{l}\text { Concentration }\left(\mathrm{mg} \mathrm{L}^{-1}\right) \\
\text { Chemical modifications } \\
\text { of rice bran }\end{array}$ & \multicolumn{6}{|c|}{ Gibbs free energy, $\Delta G_{\text {ads }}^{0}\left(\mathrm{~kJ}\right.$ mole $\left.^{-1}\right)$} \\
\hline Native & -24.1085 & -23.9816 & -23.8739 & -23.7812 & -23.5110 & -23.3366 \\
\hline $\mathrm{NaOH}$ & -19.9792 & -19.9482 & -19.9198 & -19.8925 & -19.7921 & -19.7037 \\
\hline $\mathrm{Ca}(\mathrm{OH})_{2}$ & -21.0009 & -20.9579 & -20.9171 & -20.8784 & -20.7407 & -20.6256 \\
\hline $\mathrm{Al}(\mathrm{OH})_{3}$ & -22.4066 & -22.3349 & -22.2694 & -22.2091 & -22.0100 & -21.8591 \\
\hline $\mathrm{Na}_{2} \mathrm{CO}_{3}$ & -21.1937 & -21.1476 & -21.1039 & -21.0626 & -20.9171 & -20.7969 \\
\hline $\mathrm{NaHCO}_{3}$ & -21.9785 & -21.9174 & -21.8600 & -21.8070 & -21.6273 & -21.4866 \\
\hline Esterification & -21.3143 & -21.2660 & -21.2205 & -21.1775 & -21.0270 & -20.9035 \\
\hline Methylation & -21.7442 & -21.6877 & -21.6350 & -21.5857 & -21.4165 & -21.2817 \\
\hline
\end{tabular}

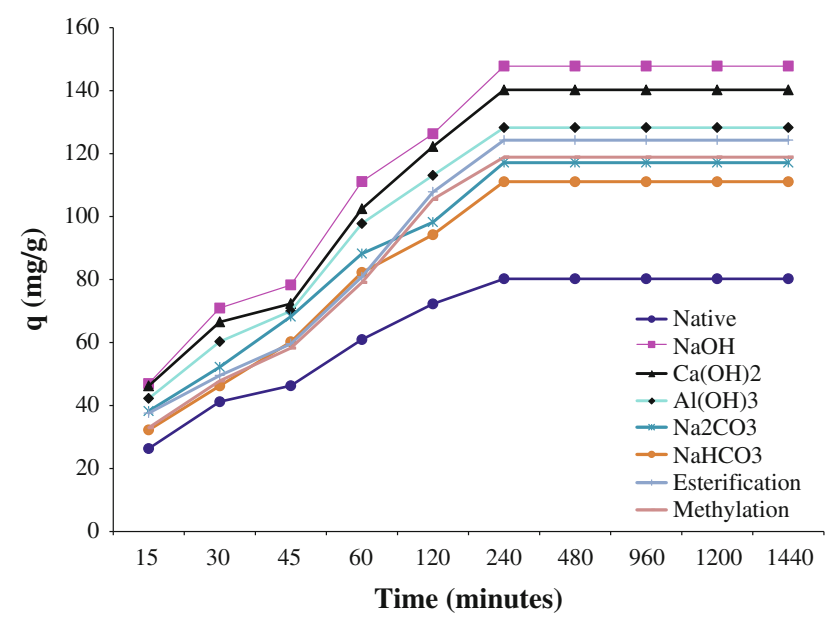

Fig. 8 Effect of contact time on the sorption of $\mathrm{Pb}(\mathrm{II})$ by chemically modified rice bran at different initial feed concentrations

Lagergren constant of the first-order sorption. Values of the rate constants $\left(K_{1}\right)$, equilibrium sorption capacity $\left[q_{\mathrm{e}}(\mathrm{cal})\right]$ and coefficient of determination $\left(R^{2}\right)$ calculated from the plots of $\log \left(q_{\mathrm{e}}-q\right)$ versus $t$ (Fig. 9) are summarized in Table 4. One can see that the rate constant $K_{1}$ ranges between $\left(4.5 \times 10^{-1}\right.$ and $\left.1.8 \times 10^{-2}\right) \mathrm{min}^{-1}$.

The integral form of the pseudo second order is commonly calculated as also proposed by (Yang et al. 2003).

$t / q=1 / k_{2} q^{2}+1 / q_{\mathrm{e}} t$

where $k_{2}\left(\mathrm{mg} \mathrm{g}^{-1} \mathrm{~min}\right)$ is the rate constant of the secondorder sorption. The values of rate constants $\left(K_{2}\right)$, equilibrium sorption capacity $\left[q_{\mathrm{e}}(\mathrm{cal})\right]$ and the coefficient of determination $\left(R^{2}\right)$ were calculated. The validity of the model can be studied by linear plotting of $t / q$ versus time represented in Fig. 10. The value of $k_{2}$ and $q_{\mathrm{e}}$ (cal) can be obtained from the slope and intercept of the line, respectively. It is clear that the values of the rate constant $\mathrm{k}_{2}$ lie between $\left(1.1 \times 10^{-4}\right.$ to $\left.9.9 \times 10^{-4}\right)$. As shown in Table 4, the coefficient of determination $\left(R^{2}\right)$ of the linear regression of Eq. 11 is low, ranging from 0.893 to 0.984 . These results suggest that the pseudo first-order model does not

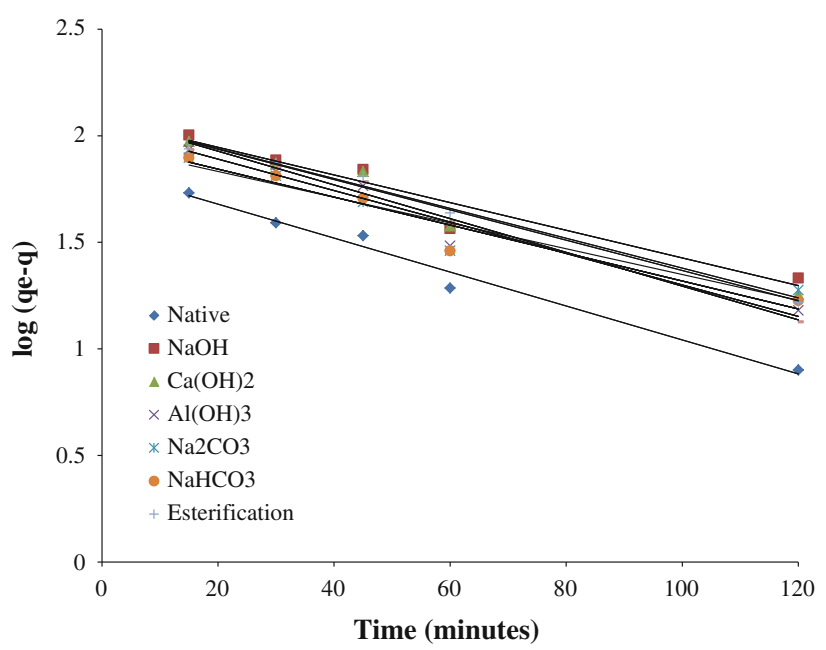

Fig. 9 Pseudo-first-order sorption kinetics plot of $\mathrm{Pb}$ (II) by chemically modified rice bran

describe the sorption kinetics of the system studied. Kinetic data were further treated with the pseudo second-order kinetic model. To quantify the validity of both models, the correlation coefficient, $R^{2}$, demonstrated that the pseudo second-order model was integral to the sorption mechanism as compared to the pseudo first-order model. The correlation coefficient of determination $\left(R^{2}\right)$ of the secondorder kinetic model was very close to unity (0.999), and the calculated $q_{\mathrm{e}}$ value also agrees with the experimental value (Table 4). These results show that $\mathrm{Pb}(\mathrm{II})$ biosorption occurs parallel to the second-order kinetic model, suggesting chemisorptions may be the rate-limiting mechanism.

\section{Conclusion}

Removal of $\mathrm{Pb}$ (II) from aqueous solutions is possible using many plentifully accessible agricultural residues. Based on the present research, the various easy and inexpensive chemical modifications of rice bran improve the sorption capacity of native rice bran. The maximum sorption 
Table 4 Kinetic model parameters for the sorption of $\mathrm{Pb}$ (II) using chemically modified rice bran

\begin{tabular}{|c|c|c|c|c|c|c|c|}
\hline \multirow{2}{*}{$\begin{array}{l}\text { Chemical } \\
\text { modifications } \\
\text { of rice bran }\end{array}$} & \multicolumn{3}{|c|}{$\begin{array}{l}\text { Pseudo first-order kinetic } \\
\text { parameters }\end{array}$} & \multirow{2}{*}{$\begin{array}{l}\operatorname{Exp} q \\
q_{\max }\left(\mathrm{mg} \mathrm{g}^{-1}\right)\end{array}$} & \multicolumn{3}{|c|}{$\begin{array}{l}\text { Pseudo second-order kinetic } \\
\text { parameters }\end{array}$} \\
\hline & $q_{\mathrm{e}}\left(\mathrm{mg} \mathrm{g}^{-1}\right)$ & $K_{1}$ & $R^{2}$ & & $q_{\mathrm{e}}\left(\mathrm{mg} \mathrm{g}^{-1}\right)$ & $K_{2}$ & $R^{2}$ \\
\hline Native & 99.70 & $4.5 \times 10^{-1}$ & 0.901 & 80.24 & 93.40 & $2.8 \times 10^{-4}$ & 0.991 \\
\hline $\mathrm{NaOH}$ & 167.4 & $3.8 \times 10^{-1}$ & 0.932 & 147.7 & 200.0 & $9.9 \times 10^{-4}$ & 0.992 \\
\hline $\mathrm{Ca}(\mathrm{OH})_{2}$ & 165.1 & $4.0 \times 10^{-1}$ & 0.893 & 139.0 & 166.0 & $1.3 \times 10^{-4}$ & 0.995 \\
\hline $\mathrm{Al}(\mathrm{OH})_{3}$ & 154.8 & $4.2 \times 10^{-1}$ & 0.912 & 127.2 & 151.5 & $1.5 \times 10^{-4}$ & 0.998 \\
\hline $\mathrm{Na}_{2} \mathrm{CO}_{3}$ & 89.12 & $1.3 \times 10^{-2}$ & 0.912 & 117.1 & 136.9 & $1.7 \times 10^{-4}$ & 0.993 \\
\hline $\mathrm{NaHCO}_{3}$ & 93.32 & $1.5 \times 10^{-2}$ & 0.930 & 117.0 & 135.1 & $1.4 \times 10^{-4}$ & 0.998 \\
\hline Esterification & 120.0 & $1.6 \times 10^{-2}$ & 0.980 & 124.2 & 156.2 & $1.0 \times 10^{-4}$ & 0.999 \\
\hline Methylation & 121.8 & $1.8 \times 10^{-2}$ & 0.984 & 118.8 & 149.2 & $1.1 \times 10^{-4}$ & 0.999 \\
\hline
\end{tabular}

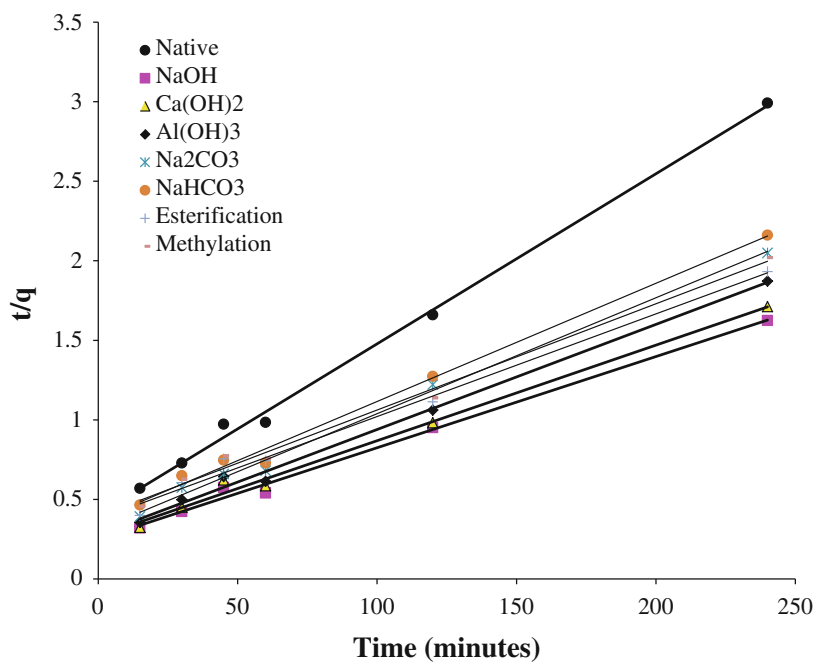

Fig. 10 Pseudo-second-order sorption kinetics plot of $\mathrm{Pb}(\mathrm{II})$ by chemically modified rice bran

capacity showed by $\mathrm{NaOH}$ chemically modified rice bran and the adsorption capacity increased in the following order: native $<\mathrm{NaHCO}_{3}<\mathrm{Na}_{2} \mathrm{CO}_{3}<$ methylation $<$ esterification $>\mathrm{Al}(\mathrm{OH})_{3}<\mathrm{Ca}(\mathrm{OH})_{2}<\mathrm{NaOH}$ by increases in the metal concentration, and the \% removal was maximum at $100 \mathrm{mg} \mathrm{L}^{-1}$. Equilibrium modeling indicates that the Langmuir isotherm plot has better correlation with the experimental data. Thermodynamic judgment explained the feasibility and spontaneous nature of the process, and $\Delta G_{\text {ads }}^{0}$ ranged from -19.7037 to -24.1085 in the concentration range $50-600 \mathrm{mg} \mathrm{L}^{-1}$ indicating physical as well as chemical sorption. The outcomes showed that $\mathrm{Pb}$ (II) biosorption occurs parallel to the second-order kinetic model, signifying that chemisorptions may be a rate-limiting mechanism. Batch experiments illustrated that the $\mathrm{pH}$ sorbate concentration and contact time extremely influence the sorption process. Thus, the overall study indicates an enhancement in the sorption capacity $\left(\mathrm{mg} \mathrm{g}^{-1}\right)$ of rice bran from 80.24 to 147.78 by different chemical pretreatments. Thus, chemically modified rice bran, particularly pretreated with $\mathrm{NaOH}$, was a successful biomaterial and proved to have a potential for industrial applications for eridicating $\mathrm{Pb}(\mathrm{II})$ from wastewater.

Acknowledgments Authors are very grateful to Prof. Dr. Munir Ahmad Sheikh (Chairman, Department of Chemistry, University of Agriculture, Faisalabad, Pakistan) for supporting this work.

\section{References}

Amuda OS, Giwa AA, Bello IA (2007) Removal of heavy metal from industrial wastewater using modified activated coconut shell carbon. Biochem Eng J 36(2):174-181

Bulut Y, Baysal Z (2006) Removal of Pb(II) from wastewater using wheat bran. J Environ Manag 78(2):107-113

Chang CY, Tsai WT, Ing CH, Chang CF (2003) Adsorption of polyethylene glycol (PEG) from aqueous solution onto hydrophobic zeolite. J Coll Interf Sci 260(2):273-279

Chang P, Wang X, Yu S, Wu W (2007) Sorption of Ni(II) on Narectorite from aqueous solution: effect of $\mathrm{pH}$, ionic strength and temperature. Colloids Surf A 302(1-3):75-81

Costodes VCT, Fauduet H, Porte C, Delacroix A (2003) J Hazard Mater 105(1-3):121-142

Dakiky M, Khamis M, Manassra A, Mereb M (2002) Selective adsorption of chromium(VI) in industrial wastewater using lowcost abundantly available adsorbents. Adv Environ Res 6(4):533-540

Diniz V, Volesky B (2005) Effect of counter ions on lanthanum biosorption by Sargassum polycystum. Water Res 39(11): 2229-2236

Faisal M, Hasnain S (2004) Microbial conversion of Cr(VI) into $\mathrm{Cr}(\mathrm{III})$ in industrial effluent. Afr J Biotechnol 3(11):610-617

Feng N, Guo X, Liang S (2010) Enhanced Cu (II) adsorption by orange peel modified with sodium hydroxide. Trans Nanoferrous Metals Soc China 20(1):146-152

Gadd GM (1988) Accumulation of metals by microorganisms and algae. In: Rem HJ (ed) Biotechnology. Germany, Weinheim, pp 401-433

Hanif MA, Nadeem R, Bhatti HN, Ahmad NR, Ansari TM (2007) $\mathrm{Ni}$ (II) biosorption by Cassia fistula (Golden Shower) biomass. J Hazard Mater B 139:345-355 (View Record in Scopus I Cited By in Scopus (59))

Ho YS, Mckay G (1999) Pseudo-second order model for sorption processes. Proc Biochem 34(5):451-465

Holan ZR, Volesky B (1994) Biosorption of lead and nickel by biomass of marine algae. Biotechnol Bioeng 1994(43):1001-1009 
Jnr MH, Spiff AI (2005) Effect of metal ion concentration on the biosorption of $\mathrm{Pb}^{2+}$ and $\mathrm{Cd}^{2+}$ by Caladium bicolor (wild cocoyam). Afr J Biotechnol 4(2):191-196

Jude CI, Augustin AA (2003) Maize cob and husk as adsorbents for removal of $\mathrm{Cd}, \mathrm{Pb}$ and $\mathrm{Zn}$ ions from wastewater. Phys Sci 2(2003):83-94

Kapoor A, Viraghran T (1997) Heavy metal biosorption sites in Aspergillus niger. Bioresour Tech 61(3):221-227

Kapoor A, Viraraghavan T (1995) Fungal-biosorption: an alternative treatment option for heavy metal bearing wastewater: a review. Biores Technol 53(1995):195-206

Kim LH, Kim KB, Lim KH, Ko SO (2005) 10th International conference on urban drain. Copenhagen, Denmark

Kleinert TN (1966) Mechanism of alkaline delignification free radical reactions, TAPPI 49 (1966), pp 126-130. View Record in Scopus. I Cited By in Scopus (8)

Kratochvil D, Volesky B (1998) Biosorption of Cu from ferruginous wastewater by algal biomass. Water Res 32(9):2760-2768

Lee HS, Volesky B (1997) Interaction of light metals and protons with seaweed biosorbent. Water Res 31(12):3082-3088

Li Q, Zhai J, Zhang W, Wang M, Zhou J (2007) Kinetic studies of adsorption of $\mathrm{Pb}(\mathrm{II}), \mathrm{Cr}(\mathrm{II})$ and $\mathrm{Cu}$ (II) from aqeous solution by sawdust and modified peanut husk. J Hazard Mater 41(1):163-167

Mahvi AH, Naghipour D, Vaezi F, Nazmara S (2005) Tea waste as an adsorbent for heavy metal removal from industrial wastewater. Am J Appl Sci 2(1):372-375

Mehrasbi MR, Farahmandkia Z, Taghibeigloo B, Taromi A (2009) Adsorption of lead and cadmium from aqueous solution by using almond shells. Water Air Soil Pollut 199(1-4):343-351

Michael HJ, Ayebaemi IS (2005) Effects of temperature on the sorption of $\mathrm{Pb}^{+2}$ and $\mathrm{Cd}^{+2}$ from aqueous solution by caladium bicolor (wild cocoyam) biomass. Environ J Biotechnol 8(2): 162-169

Mosa AA, Ghamry A, Truby P (2011) Chemically modified crop residue as a low cost technique for the removal of heavy metal ions from waste water. Water Air Soil Pollut 217(1-4):637-647

Nadeem R, Hanif MA, Shaheen F, Perveen S, Zafar MN, Iqbal T (2008) Physical and chemical modification of distillery sludge for $\mathrm{Pb}$ (II) biosorption. J Hazard Mater 150(2):335-342

Naeem A, Woertz JR, Fein JB (2006) Experimental measurement of proton, $\mathrm{Cd}, \mathrm{Pb}, \mathrm{Sr}$ and $\mathrm{Zn}$ adsorption onto fungal species Saccharomyces cerevisiae. Environ Sci Technol 40(18): 5724-5729

Nakajima A, Sakaguchi T (1990) Recovery and removal of uranium by using plant wastes. J Biomass 21(1):55-63

Nasir MH, Nadeem R, Akhtar K, Hanif MA, Khaild AM (2007) Efficacy of modified distillation sludge of rose (Rosa centifolia) petals for lead (II) and $\mathrm{Zn}$ (II) removal from aqueous solutions. J Hazard Mater 147(3):1006-1014

National Environmental Quality Standards (NEQS) of Pakistan approved by Environmental Protection Council, 28 December, 1999

Park D, Yun Y, Park JM (2005) Studies on hexavalent chromium biosorption by chemically treated biomass of Ecklonia sp. Chemosphere 60(2005):1356-1364

Preetha B, Viruthagiri T (2005) Biosorption of zinc by Rhizopus arrhizus: equilibrium and kinetic modeling. Afr J Biotechnol 4(6):506-508
Pussadee P, Apipreeya K, Prasert P (2008) Batch studies of adsorption of copper and lead on activated carbon from Eucalyptus camaldulensis Dehn bark. J Environ Sci 20(9): 1028-1034

Quality Drinking water: Guidelines and Standards for Pakistan, Ministry of Health, Health Services Academy, Islamabad, June 2005

Rehman H, Shakirullah M, Ahmad I, Sheshah H (2006) Sorption studies of nickel ions onto sawdust of Dalbergia sissoo. J Chin Chem Soc 5(3):1045-1052

Rudresh HB, Mayanna SM (1977) Adsorption of n-decylamine on zinc from acidic chloride solution. J Environ Sci Technol 122:261-266

Schiewer S, Patil SB (2008) Pectin-rich fruit wastes as biosorbents for heavy metal removal: equilibrium and kinetics. Bioresour Technol 99(6):1896-1903

Seader JD, Henley EJ (2006) Separation process principles, 2nd edn. Wiley, New Jersey

Sekhar KC, Kamala CT, Chary NS, Anjaneyulu Y (2003) Removal of heavy metals using a plant biomass with reference to environmental control. Int J Miner Process 68(1-4):37-45

Sekhar KC, Kamala CT, Chary NS, Sastry AR, Rao TN, Vairamani M (2004) Removal of lead from aqueous solutions using an immobilized biomaterial derived from a plant biomass. J Hazard Mater 108(1-2):111-117

Singh KK, Rastogi R, Hasan SH (2005) Removal of cadmium from wastewater using agricultural waste 'rice polish'. J Colloid Interf Sci 290:61-68

Sud D, Mahajan G, Kaur MP (2008) Agricultural waste material as potential adsorbent for sequestering heavy metal ions form aqueous solutions. A review. Bioresour Technol 99(14): $6017-6027$

Sun G, Shi W (1998) Sunflower stalks as adsorbents for the removal of metal ions from wastewater. Ind Eng Chem Res 37(4):13241328

Wan Ngah WS, Hanafiah MAKM (2008) Removal of heavy metal ions from wastewater by chemically modified plant wastes as adsorbents: a review. Bioresour Technol 99(10):3935-3948

Weber WJJR (1985) Adsorption theory, concepts and models. In: Slejko FL (ed) Adsorption technology: a step-by-step approach to process evaluation and application. Marcel Dekker, New York, pp 1-35

Yang XY, Otto SR, Al-Duri B (2003) Concentration dependent surface diffusivity model (CDSDM). J Chem Eng 94(3):199-209

Ye H, Zhu Q, Du D (2010) Adsorptive removal of Cd(II) from aqueous solution using natural and modified rice husk. Bioresour Technol 101(14):5175-5179

Zafar MN, Nadeem R, Hanif MA (2007) Biosorption of nickel from protonated rice bran. J Hazard Mater 143(1-2):478-485

Zafar MN, Abbas I, Nadeem R, Sheikh MA, Ghauri MA (2009) Removal of nickel on to alkali treated rice bran. Water Air Soil Pollut 197(1/4):361-370

Zeng L, Li X, Liu J (2004) Adsorptive removal of phosphate from aqueous solutions using iron oxide tailings. Water Res 38(5): 1318-1326 